\title{
Tertiary bone grafting with or without premaxilla osteotomy in adult alveolar clefts_-Techniques and early outcome
}

\author{
Oladimeji A. Akadiri ${ }^{1}$, Babatunde O. Akinbami ${ }^{1}$, Benjamin M. Kejeh ${ }^{2}$ \\ ${ }^{1}$ Department of Oral \& Maxillofacial Surgery, University of Port Harcourt, Port Harcourt, Nigeria \\ ${ }^{2}$ Department of Surgery (Plastic Surgery and Burn Unit), University of Port Harcourt, Port Harcourt, Nigeria \\ Email: oaakadiri@yahoo.com
}

Received 26 March 2012; revised 2 May 2012; accepted 12 May 2012

\begin{abstract}
The outcome of alveolar bone grafting in adult patients is sparsely reported. Here, we present a description of the surgical techniques used in a Nigerian teaching hospital and a preliminary report of the first five cases of adult alveolar cleft bone grafting accomplished with or without repositioning the premaxilla. Although, evidence of bone resorption was observed within 6 months after the operation, satisfactory bone level and aesthetic outcome was recorded in all cases. We concluded that tertiary alveolar bone grafting is desirable for all cases where alveolar clefts have persisted into adulthood to enhance the psyche of the cleft patients and to motivate them for further rehabilitation. Prompt placement of dental implant into the grafted area is recommended to mitigate subsequent resorption of the bone graft.
\end{abstract}

Keywords: Premaxilla Repositioning; Illiac Crest Bone Graft; Aesthetic Outcome; Soft Tissue Envelope

\section{INTRODUCTION}

The surgical management of congenital clefts of the dental alveolus involves among other approaches, the use of autogeneous bone graft [1]. Based on this approach, conventional bone grafting of alveolar clefts have been broadly classified into: 1) primary bone grafting, in which the cleft alveolus is usually reconstructed at the same time as closure of the cleft lip, or shortly thereafter; before age 5 years [2]; 2) secondary bone grafting, which is usually done around age 9 - 11 years upon the development of the upper canine, to facilitate the eruption of the canine into the graft and permits the maxilla to develop undisturbed [3,4] and 3) tertiary bone grafting which is performed at a later stage in adult patients [5].

Unrepaired alveolar clefts persisting into adulthood presents peculiar challenges such as increased cleft width, abnormal and excessive projection of the premaxilla, rigid and non deformable bony contour, and tension repair leading to suboptimal aesthetic outcome. The scenario is worsened where associated cleft lip and/or palate have also been neglected. These are cases for which tertiary alveolar bone grafting with or without premaxilla osteotomy is often required.

In our environment, it is not unusual to find adult patients with previously unrepaired or poorly repaired cleft lip and alveolus requiring revision. In particular, there is very high threshold for alveolar cleft repair, essentially because of lack of expertise in alveolar cleft bone grafting. The history of cleft repair at the University of Port Harcourt Teaching Hospital, Nigeria dates back to the early 1980s, yet not a single record of alveolar cleft bone grafting was found. Similarly, we did not find any publication of Nigerian origin in the world cleft literature where experience in alveolar cleft bone grafting has been reported. Therefore, this article provides a preliminary report of our experience and early outcome of tertiary alveolar bone grafting after 2 years of introducing the procedure into the cleft care protocol of our hospital. It also contains a succinct description of our techniques.

\section{TECHNIQUE FOR HARVESTING THE BONE GRAFT}

The traditional autogeneous donor sites for alveolar bone grafting include the iliac crest, the mandible (chin and ramus), the tibia and the calvarium [1]. The iliac crest is the goldstandard; it is easy to access and supplies large quantities of cancellous bone with pluripotent or osteogenic precursor cells that support early osteogenesis and neovascularization within 3 weeks after grafting [6]. Hence, it is our regular choice of donor site. We usually prefer the posterior iliac crest because it has been associated with a smaller estimated blood loss and a shorter hospital stay compared to the anterior iliac crest [7].

About $1-1.5 \mathrm{~cm}$ posterior to the anterior superior iliac 
spine, a linear incision, 4 - $5 \mathrm{~cm}$ long is made over and parallel to the iliac crest after slightly retracting the skin upward to avoid the bikini line. With gentle sharp dissection, we proceed directly to the iliac crest. After exposing the iliac crest, an osteotome is used initially to make vertical stop cuts into the iliac crest at the two ends of the incision. Further, the ostetome is used to "open” the bony crest while leaving it pedicled medially on its muscular attachments and periosteum. A curette is used to scoop cancellous bone while preserving the cortices. Sometimes the cancellous marrow is more calcified, in which case, we used fine bone nibbler to gently and gradually nibble the cancellous bone. Occasionally, we harvest a cancellous block by chiseling between the cortical plates. The graft is then gently minced and mixed into slurry with blood aspirated from the donor site. The pedicled iliac crest cap is returned like a trap door to its anatomical location and held in place with 3 - 0 vicry sutures after which the wound is closed by layers in a standard fashion [8].

\section{EXPOSURE, PREPARATION OF SOFT TISSUE ENVELOPE AND CLOSURE OF THE RECIPIENT SITE}

To achieve successful bone grafting of the cleft alveolus, the mucoperiosteum covering the cleft site must be raised to expose the underlying bones of the cleft alveolus up onto the pyriform margin of the nasal cavity. A vertical incision is made mid-way along the buccopalatal width of the cleft margin. We extend the incision as far inward as possible to raise the palatal mucoperiosteum and outward into the gingival crevice of the teeth adjoining the cleft. The gingival crevicular incision is continued along the margins of contiguous teeth until the premolar-molar junction on either side of the cleft. In case of bilateral alveolar cleft, the labial mucoperiosteum of the premaxilla segment is raised as much as possible taking care to preserve some soft tissue attachment labially and/or palatally. With this exposure, enough access is created for premaxilla osteotomy if required. Further access can be achieved by including vertical relieving incisions at the lateral ends of the crevicular incisions. The next step was to create the soft tissue pocket in which to pack the bone graft. This is done by closing the nasal floor and the palatal mucoperiosteum across the cleft site. Where no lateral relieving incisions were used, the labial mucoperioteum might have gained sufficient length with the tissue raised from the cleft margin. If not, further lengthening can be achieved by scoring the periosteal layer of the mucoperiosteum vertically about 1 - 2 tooth-width away from the cleft site. The resulting elastic extension of the soft tissue increases length. In some cases, lateral relieving incisions have to be incorporated and the cleft site is closed by lateral transposing of the labial flaps. After bone graft placement, closure of the soft tissue envelope is achieved by horizontal mattress sutures placed across the alveolar crest or by transposing an anteriorly based buccal myomucosal flap.

\section{PREMAXILLA OSTEOTOMY TECHNIQUES}

Following exposure of the bony elements of the cleft site, the prominent premaxilla is osteotomised depending on the extent and direction of flaring. We have employed three types of osteotomies. Type I involves block excision of a small bony segment from the vomeromaxillary complex to achieve a set-back of the premaxilla (Figure 1). This is indicated in cases of bilateral cleft involving the primary palate in which the anterior projection of the premaxilla is limited, especially where a previous poor attempt at lip repair or an initial lip adhesion has helped to restrict the proclination of the premaxilla (see Patient 1 in Figure 2). Type II involves a wedge excision and down rotation at the vomeromaxillary suture (Figure 3 ). Similarly, this is indicated in cases of bilateral cleft involving the primary palate where the premaxilla has grown unhindered such as where lip repair had been delayed until adolescence/adulthood (see Patient 4 in Figure 4) or where the lip was not repaired. Type III is a horizontal buccal plate grooving beneath the pyriform margin followed by down fracture (Figure 5) and it is indicated in unilateral cleft where the premaxilla is rotated outward on the cleft side (see Patient 2 in Figure 6).

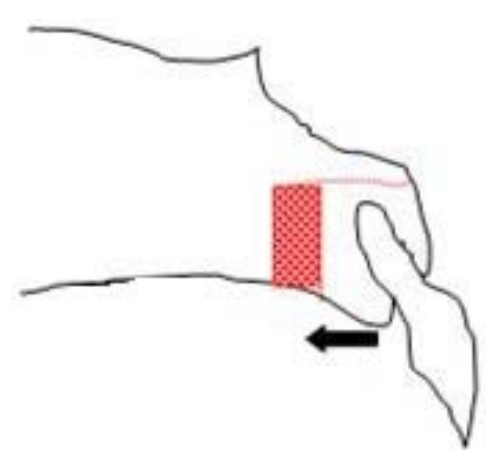

Figure 1. Block osteotomy and setback to retroposition the premaxilla.

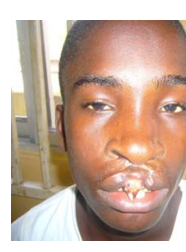

(a)

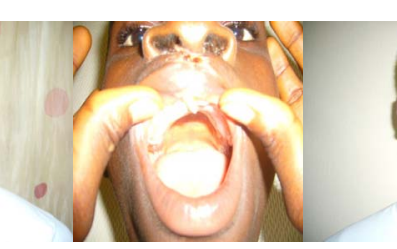

(b)

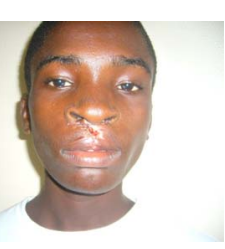

(c)
Figure 2. (a) Preoperative photograph showing protrusive prolabium; (b) Postoperative photograph showing acryllic palatal stent; (c) One week postoperative view immediately after suture removal. 


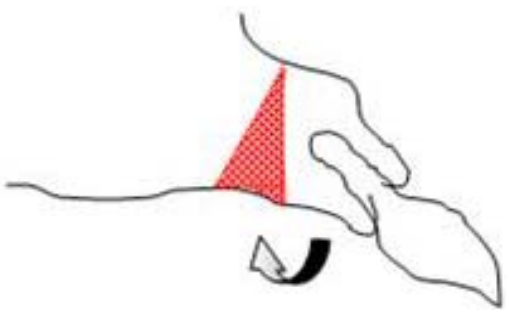

Figure 3. Wedge osteotomy and downrotation of the premaxilla.

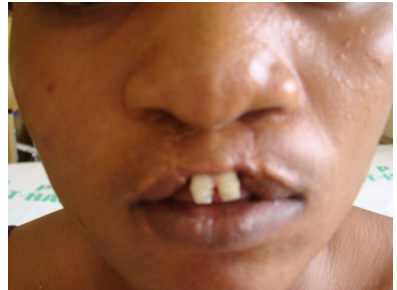

(a)

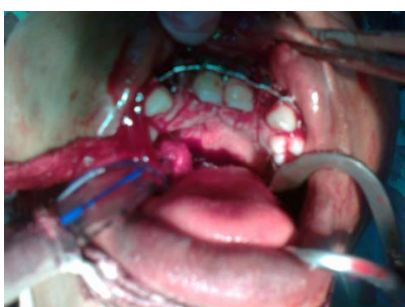

(c)

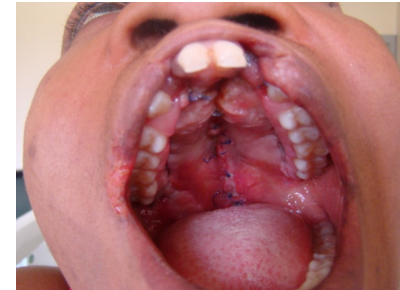

(b)

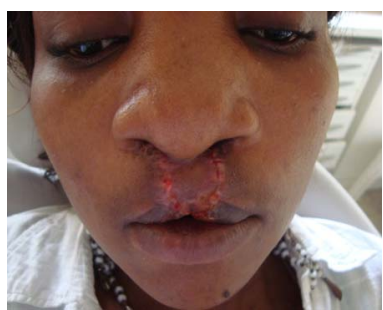

(d)
Figure 4. (a) At presentation showing previous lip repair and complete palatal cleft (Inset); (b) After stage I (Palatoplasty) procedure; (c) Intraoperative photograph showing Erlich arch bar splinting of the repositioned premaxilla; (d) One week after lip revision.

\section{GRAFTING AND SPLINTING}

After osteotomy and fabrication of the soft tissue pocket, cancellous chips are picked with broad-face non tooth tissue forceps and packed into the soft tissue pockets as far as the pyriform margin and alar base and compacted incrementally until the whole cleft defect is filled with bone grafts in three dimensions. It is important to maintain the osteotomised segment in its final position while the bone graft is being packed and compacted to enhance its stability. The process of compacting the bone is said to increase the number of osteogenic cells/unit volume of cancellous bone which is thought to increase its reliability even further $[9,10]$. We assure stability of the osteotomised alveolar segment by splinting the standing teeth with an Erlich arch bar (Figure 4) which is malleable but yet provides sufficient rigidity otherwise, we employed an acryllic palatal stent (Figure 2).

\section{OUTCOMES IN FIVE ADULT PATIENTS}

Within 2 years of instituting alveolar bone grafting into

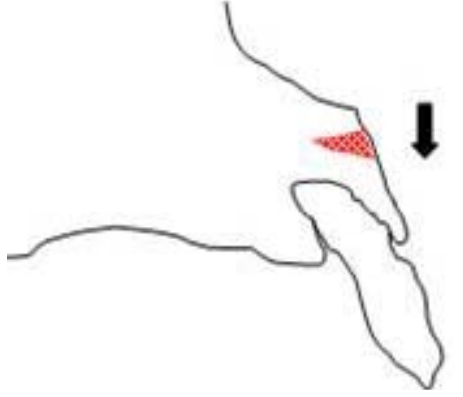

Figure 5. Buccal grooving/osteotomy and downfracture of the premaxilla.

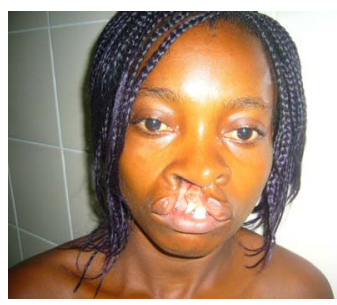

(a)

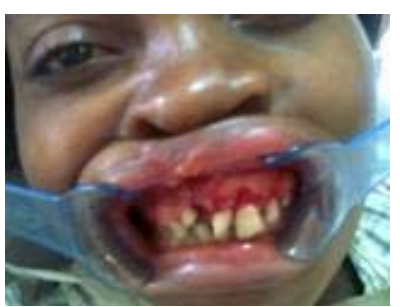

(c)

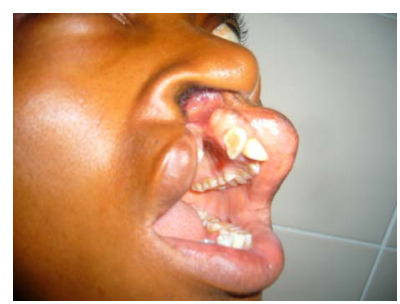

(b)

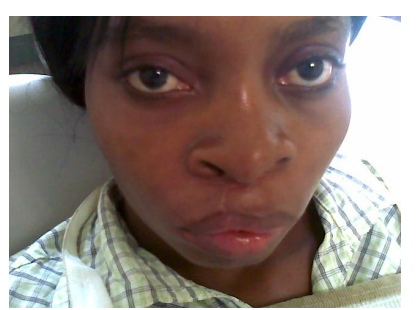

(d)
Figure 6. (a) Preoperative photograph showing lip and alveolar cleft; (b) Preoperative side of cleft alveolus; (c) 3 months after alveolar defect repair; (d) 3 months postoperative facial appearance.

the cleft care protocol of our centre, we have performed tertiary bone grafting in 5 adult patients including 2 bilateral and 3 unilateral cases (Table 1). The patients were made up of one male and four females of age 18 - 29 years. Patients 3 and 4 had their cleft lips previously repaired in another facility while patient 3 only had cleft palate repaired before presenting in our hospital. However, in all of these cases the alveolar cleft had been neglected. Other patients presented in our hospital for primary repair of their cleft lip/alveolus and/or palate. One stage repair was performed in all, except patient 4 who had multiple staged procedures because she had low Haemoglobin level and had refused blood transfusion on religious ground.

The surgical outcome evaluation was based on three broad criteria; the radiographic outcome, the aesthetic outcome and post surgical morbidity.

\subsection{Radiographic Outcome}

Periapical radiographs were taken at 3 and 6 months 
Table 1. Patients' characteristics, procedures and post surgical outcome of management of adult alveolar cleft at UPTH.

\begin{tabular}{|c|c|c|c|c|c|c|}
\hline \multirow{2}{*}{$\begin{array}{l}\text { Patient } \\
\text { ID }\end{array}$} & \multirow{2}{*}{ Demographics } & \multirow{2}{*}{ Features } & \multirow{2}{*}{ Procedure } & \multicolumn{3}{|c|}{ Post surgical outcome } \\
\hline & & & & $\begin{array}{l}\text { Radiographic } \\
\text { outcome }\end{array}$ & Aesthetic Outcome & Morbidity \\
\hline Patient 1 & $\begin{array}{l}\text { Age: } 18 \text { years } \\
\text { Sex: Male }\end{array}$ & $\begin{array}{l}\text {-Bilateral alveolar cleft } \\
\text {-Protrusion of the } \\
\text { premaxilla } \\
\text {-Bilateral cleft lip }\end{array}$ & $\begin{array}{l}\text { One stage: } \\
\text {-Premaxilla osteotomy and } \\
\text { set-back } \\
\text {-Bone grafting } \\
\text {-Acrylic palatal stent for } 3 \\
\text { months } \\
\text {-Primary repair of bilateral } \\
\text { cleft lip }\end{array}$ & $\begin{array}{l}\text { Bergland score: } \\
3 \text { months: Type I } \\
6 \text { months: Type II }\end{array}$ & $\begin{array}{c}\text { IO: Good } \\
\text { PR: } \\
\text { Very satisfactory }\end{array}$ & $\begin{array}{l}\text { No complications } \\
\text { Hospital stay: } \\
7 \text { days }\end{array}$ \\
\hline Patient 2 & $\begin{array}{l}\text { Age: } 20 \text { years } \\
\text { Sex: Female }\end{array}$ & $\begin{array}{l}\text {-Complete unilateral } \\
\text { alveolar cleft } \\
\text {-Unilateral cleft lip }\end{array}$ & $\begin{array}{l}\text { One stage: } \\
\text {-Vomeromaxillary osteotomy } \\
\text { and down fracture } \\
\text {-Bone grafting } \\
\text {-arch bar splint } \\
\text {-Primary unilateral cleft repair }\end{array}$ & $\begin{array}{l}\text { Bergland score: } \\
3 \text { months: Type I } \\
6 \text { months: Type II }\end{array}$ & $\begin{array}{c}\text { IO: Very good } \\
\text { PR: Very satisfactory }\end{array}$ & $\begin{array}{c}\text { Gait disturbance: } \\
3 \text { days } \\
\text { Hospital stay: } \\
10 \text { days }\end{array}$ \\
\hline Patient 3 & $\begin{array}{l}\text { Age: } 29 \text { years } \\
\text { Sex: Female }\end{array}$ & $\begin{array}{l}\text {-Complete unilateral } \\
\text { cleft of primary \& } \\
\text { Secondary palate } \\
\text {-Previous hard \& soft } \\
\text { palate repair } \\
\text {-Previous lip repair } \\
\text {-Neglected alveolar } \\
\text { cleft }\end{array}$ & $\begin{array}{l}\text { One stage: } \\
\text {-Vomeromaxillary osteotomy } \\
\text { and down fracture } \\
\text {-Bone grafting } \\
\text {-arch bar splint } \\
\text {-Revision of cleft lip }\end{array}$ & $\begin{array}{l}\text { Bergland score: } \\
3 \text { months: Type I } \\
6 \text { months: Type II }\end{array}$ & $\begin{array}{c}\text { IO: Good } \\
\text { PR: Satisfactory }\end{array}$ & $\begin{array}{c}\text { Gait disturbance: } \\
5 \text { days } \\
\text { Hospital stay: } \\
5 \text { days }\end{array}$ \\
\hline Patient 4 & $\begin{array}{l}\text { Age: } 29 \text { years } \\
\text { Sex: Female }\end{array}$ & $\begin{array}{l}\text {-Complete bilateral } \\
\text { cleft of primary \& } \\
\text { secondary palate } \\
\text {-Previous lip repair }\end{array}$ & $\begin{array}{l}3 \text { stages: } \\
\text {-Stage 1: palatoplasty } \\
\text {-Stage 2: Alveolarbone } \\
\text { grafting } \\
\text {-Stage 3: Lip revision }\end{array}$ & $\begin{array}{l}\text { Bergland score: } \\
3 \text { months: Type I } \\
6 \text { months: Type II }\end{array}$ & $\begin{array}{c}\text { IO: Good } \\
\text { PR: Very satisfactory }\end{array}$ & $\begin{array}{c}\text { Gait disturbance: } \\
7 \text { days } \\
\text { LFCN paraethesia: } \\
2 \text { weeks } \\
\text { Hospital stay: } 9 \text { days }\end{array}$ \\
\hline Patient 5 & $\begin{array}{l}\text { Age: } 25 \text { years } \\
\text { Sex: Female }\end{array}$ & $\begin{array}{l}\text {-Complete unilateral } \\
\text { alveolar cleft } \\
\text {-Unilateral cleft lip }\end{array}$ & $\begin{array}{l}\text { One stage: } \\
\text {-Alveolar bone grafting } \\
\text {-Primary lip repair }\end{array}$ & $\begin{array}{l}\text { Bergland score: } \\
3 \text { months: Type I } \\
6 \text { months: Type II }\end{array}$ & $\begin{array}{c}\text { IO: Good } \\
\text { PR: Very satisfactory }\end{array}$ & $\begin{array}{c}\text { Gait disturbance: } \\
4 \text { days } \\
\text { Hospital stay: } 6 \text { days }\end{array}$ \\
\hline
\end{tabular}

postoperative period and the level of osseous bridging of the alveolar cleft was assessed using the Bergland scoring index. All the patients had Bergland type I at 3 months while the bone level at 6 months review were Bergland Type II in all cases. (Table 2, Figure 7)

\subsection{Aesthetic Outcome}

The aesthetic outcome was assessed semi-objectively in each case by three independent observers namely; a dental nurse, a non clinical staff and a patient relation. The same dental nurse and non clinical staff assessed all cases. The assessment was based on a visual analog scale (VAS) ranged 0 - 10. Zero implied no change, 1 - 3 was poor outcome, 4 - 6 was good outcome, 7 - 10 was very good outcome. At least the assessment by two observers must tally. Where one observer differed from others, the worst assessment was adopted. There was no case of disagreement between the three independent observers.
Patient's rating (subjective assessment) was based on similar VAS where 0 implied failed procedure (breakdown and graft loss), 1 - 3 represented unsatisfactory outcome, 4 - 6 was satisfactory outcome and 7 - 10 was very satisfactory outcome.

In all cases, independent observers' rating (IO) ranged between "good” and “very good” while patients' rating (PR) ranged between satisfactory and very satisfactory (Table 1).

\subsection{Morbidity}

There were no significant complications from both the donor and recipient sites other than gait disturbance noted in patients 2, 3, 4 and 5 which lasted between 3 - 7 days (Table 1) and significant paraesthesia of the lateral cutaneous femoral nerve (LCFN) in patient 4. The duration of hospital stay as a result of this treatment was between 5 - 10 days with a mean stay of one week. 
Table 2. Bergland scoring index.

Type I: Bony bridge up to the level of normal alveolar crest. Type II: Bony bridge of 3/4 normal alveolar height.

Type III: Bony Bridge greater than half but less than 3/4 of normal height.

Failure: No bony bridge across the cleft achieved.

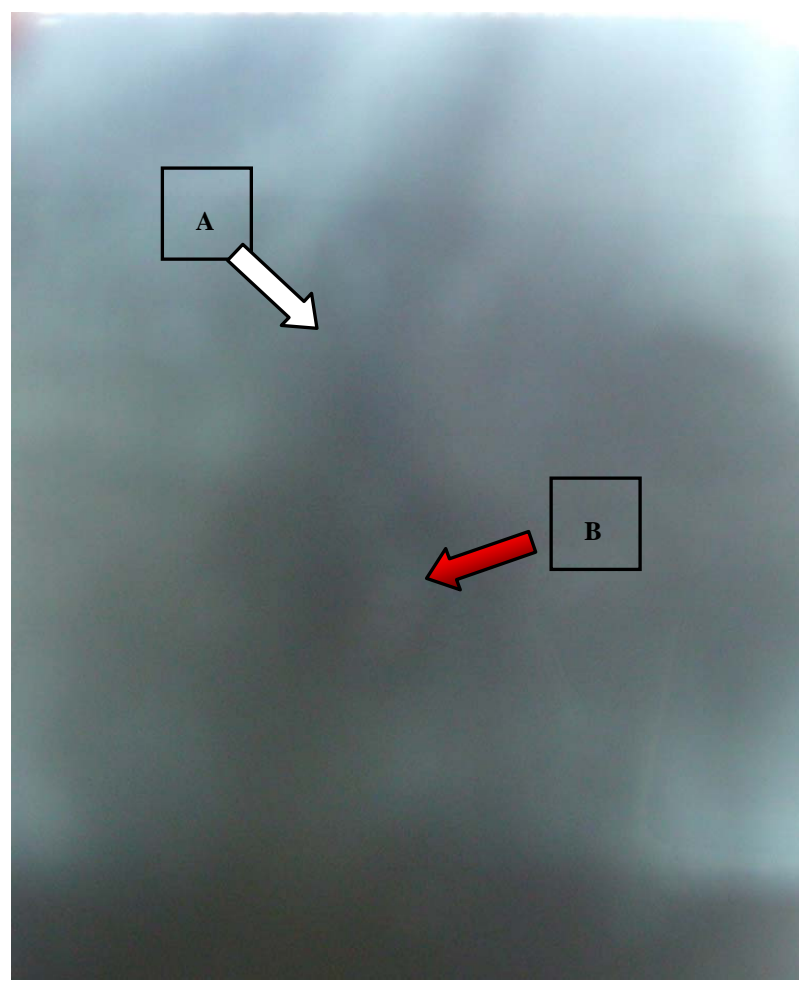

Figure 7. Periapical radiograph taken 3 months after alveolar bone grafting. A: White arrow indicating the margin of grafted alveolar defect; B: Red arrow indicating bone graft up to the alveolar crestal margin.

\section{DISCUSSION}

Joseph Daw and Pravin Katel [11] observed that historically, the management of alveolar clefts has lagged behind the surgical correction of cleft lip and palate in terms of appreciating its significance and in the evolution of surgical techniques. This apparent lack of cognizance reflects in our environment where many adult patients live with alveolar cleft deformity despite having had their cleft lips and palates repaired. Even from some more surgically developed environments where alveolar bone grafting is already a common place, very few reports on the outcome of adult alveolar bone grafting emanate. This article reports the early outcome of tertiary alveolar bone grafting in our center and the rationale for our techniques.

The choice of iliac crest as a cancellous bone resource for alveolar bone grafting is well supported in the literature $[1,4,12-14]$. It has easy access, large quantity, easy compaction, rich and rapid revascularization, high volume of osteogenic precursor cells and relatively low donor site morbidity as advantages over cranial, tibia and mandibular bones $[1,6,15,16]$. Although our harvesting technique is not significantly different from the one described by Boyne and sands [12], we introduced stop cuts at either end of the exposed iliac crest and found it very helpful in preserving the integrity of the iliac crest cap while flipping it medially. Also, when we observe greater density of the cancellous marrow which made scooping fairly difficult, we either nibbled the bone bit by bit or made block cuts by chiseling around to create a chunk of cancellous block between the outer and inner cortical plates. The isolated block was then segmented into smaller blocks by vertical osteotomies. Each small block then became easy to fracture from the base by holding and wiggling with an instrument e.g. an Allis forceps. This block harvest is usually minced and mixed with blood but in some areas such as the alveolar crestal defect, it is sometimes helpful to bridge with a small block of cancellous bone which fits snugly. This acts as a stopper and prevents the deeper cancellous chips from being displaced.

It is most essential to prepare adequate soft tissue envelope before packing and compacting the cancellous chips into the defect. To achieve this, the mucoperiosteal flaps were extensively elevated to expose areas for graft augmentation. Latching on the distensibility of the flap and the additional length gained by incorporating the portion elevated from the cleft edges, closure of the mucosal gap was easier for clefts of smaller width. Where further lengthening was desirable, scoring the periosteum about 2 tooth-widths away enhances stretching. Larger mucosal gap was closed by lateral transposition of the labial mucoperiosteal flaps with or without a buccal myomucosal flap pedicled anteriorly. The objective is to ensure adequate coverage of the grafts while ensuring tension free closure. Uneventful soft tissue healing is critical to the success of the graft. Some surgeons have enhanced this potential by incorporating platelet rich plasma (PRP) into the graft. The PRP gel, apart from enhancing graft take provides haemostatic adhesion properties and supplies the wound with valuable growth factors that enhance and promote the healing process. [17-20].

Persistent unhindered growth of the premaxilla in adult alveolar cleft presents the worst deformation in bilateral cases where presurgical orthopaedics and/or cleft lip repair were not performed earlier. Some unilateral alveolar clefts will also require premaxilla osteotomy and repositioning where cleft lip repair had been neglected or overly delayed. Some authors advocated the amputation of the premaxilla [21], while others prefer to reposition it [22]. Where possible, it is preferable to pre- 
serve the native bone of the premaxillary segment so that amputation should be the last resort. Our choice was osteotomy and repositioning. This must be done carefully to avoid the sequestration of the segment. The premaxilla segment derives it blood supply majorly from the palatal and labial periosteal vessels and could be deprived with excessive stripping and osteotomy. It is desirable to preserve some soft tissue pedicle either labially or palatally. Exposure should be just sufficient to access for osteotomy and grafting. Depending on the projection of the segment, different approaches to the osteotomy have been described. Our osteotomy techniques involved block osteotomy at the vomero-premaxilla complex and retro positioning where the premaxilla was more vertically oriented but anteriorly protrusive, usually in bilateral cases. For excessively proclined premaxilla, wedge osteotomy and downward rotation was appropriate. In most unilateral cases of neglected cleft of the primary palate, outward rotation of the minor segment sometimes requires osteotomy. This we accomplished by grooving the buccal plate horizontally above the apices of the anterior teeth about 1 - $2 \mathrm{~mm}$ beneath the pyriform margin. The weakened plate was then down fractured and maintained by arch bar splinting.

Outcome of alveolar bone grafting is most appropriately assessed in terms of the amount of osseous bridging achieved in three dimension, the aesthetic and functional outcome viz-a-viz the morbidity associated with the procedure. In this preliminary report, osseous bridging was assessed in two dimensions with periapical radiograph and the result as at 6 months post grafting was quite satisfactory. However, the reduction in bone level at 3 month interval observed in all patients is a cause for concern. The low success rate with alveolar graft in older patients has been variously reported. It is adduced partly to cementum exposure of the teeth adjoining the cleft site which prevent adequate interosseous bonding between the graft and the native bone [11]. And more importantly to rapid bone resorption associated with various factors in the adult patient such as the timing of the operation, absence of functional stress on the bone due to loss of eruptive potential or aplasia of teeth in the area [23], poor dental hygiene and periodontal infection, the width of the cleft [24,25], and skills of the surgeon [26,27]. Racial or ethnic factors is another factor reported to influence the take of alveolar bone graft and the whites are said to produce better outcome compared to the Blacks [28].

Although the bone level at 6 month in our 5 patients was still satisfactory, it is well known that grafted bone undergoes resorption in 3 dimensions [14,29-31] while we have only assessed in 2 dimensions. In a previous study, the volume of the grafted alveoli at one year was significantly decreased compared with that at 3 months
[32]; and in other studies, approximately 30\% of the volume of bone transplanted from the iliac crest had been resorbed in the first year [29,30,33], and the total volume loss was approximately $43.1 \%$ at one year after secondary alveolar cleft repair from the iliac crest [31]. To mitigate alveolar graft bone resorption the placement of dental implants no longer than 4 - 6 months after bone grafting has been recommended [34]. The advantages of dental implants include cosmetic reconstruction of the dental arch, to facilitate orthodontic treatment and to support functioning occlusal force which helps to maintain the restored bone height $[33,35,36]$.

The most fascinating outcome to our patients was the aesthetic improvement of their facial appearance and oral outlook. This had significant psychological impact on the patient who in spite of the yet suboptimal outcome felt very satisfied and more confident to interact socially. However, considering that this was an early outcome and the high potential for bone resorption as time goes by, a lot more is required in terms of dental implant placement and orthodontic/prosthetic rehabilitation. Although highly motivated to undertake further rehabilitative treatments, the patients were unfortunately usually very indigent and would require financial support to gain maximally from the possibilities that are now available for the complete aesthetic restoration of a congenital cleft patient.

Morbidity associated with alveolar bone grafting procedures results from complications at both the cleft site and the donor site. Reported Complications at the cleft site include bleeding, pain, wound breakdown and bone loss, infection, bone sequestration, bone resorption, residual fistulae, loss of vestibular depth, gingival hyperplasia, injury to adjacent teeth, external bone resorption and rarely cyst formation in the grafted bone [37]. No wound dehiscence, bone graft exposure or bone graft infection was found postoperatively in our cases.

The main criticism of the use of the iliac crest for alveolar bone grafts is postoperative pain that limits walking and results in a prolonged stay in hospital and prolonged recovery [6]. Other possibilities are infection and lateral cutaneous femoral neuropathy. Worse complications of iliac crest donor site such as paralytic illeus, retroperitoneal heamorhage etc. are uncommon in the scenario of alveolar bone grafting where exposure is particularly conservative and only the particulate bone cancellous marrow is harvested. Four of our patients had disturbance to walking lasting 4 - 7 days but the patients were all able to walk unsupported by the third postoperative days and the gait disturbances were not sufficient to prolong hospital stay. Only one patient experienced paraesthesia of lateral femoral cutaneous nerve which improved significantly in 4 days.

Currently, the reported length of stay in hospital after bone is harvested from the iliac crest varies widely. Ber- 
gland et al. [3] discharged patients six days after operation, which is longer than the 3.6 - 3.8 days reported by Troxell et al. [38] and Hall and Posnick [39]. In our practice, other factors such as ability to maintain proper home care and personal hygiene influence our time of discharge. Based on the procedures we did, most of our patients were able to go home by $5^{\text {th }}$ postoperative day, but we delayed to discharge where we were not satisfied with patients efforts to maintain home care and personal hygiene until we felt it was safe to do so.

\section{CONCLUSION}

Report of tertiary alveolar bone grafting is sparse in the world cleft literature. To the best of our knowledge, this is the first Nigerian report on alveolar cleft grafting, especially as it relates to adult patients. Although no generalization could be made from these outcomes due to the few patients involved, the techniques which we described here seem to yield satisfactory outcome for older cleft patients. In environments where cleft deformities are allowed to persist into adulthood either due to lack of awareness, finance or expertise, there will always be the challenge of adult alveolar cleft grafting. The early outcome in our experience is impressive and very useful to enhance the psyche of the cleft patients and to motivate them for further rehabilitation.

\section{REFERENCES}

[1] Eppley, B.L. and Sadove, A.M. (2000) Management of alveolar cleft bone grafting-State of the art. Cleft Palate-Craniofacial Journal, 37, 229-233. doi:10.1597/1545-1569(2000)037<0229:MOACBG >2.3. $\mathrm{CO} ; 2$

[2] Witsenburg, B. (1985) The reconstruction of anterior residual bone defects in patients with cleft lip, alveolus and palate: A review. Journal of Oral and Maxillofacial Surgery, 13, 197-208.

[3] Bergland, O., Semb G. and Abyholm, F. (1986) Elimination of residual alveolar cleft by secondary bone grafting and subsequent orthodontic treatment. Cleft Palate Journal, 23, 175-205.

[4] Enemark, H., Sindet-Pedersen, S. and Bundgaard, M. (1987) Long-term results after secondary bone grafting of alveolar clefts. Journal of Oral and Maxillofacial Surgery, 45, 913-914. doi:10.1016/0278-2391(87)90439-3

[5] Van der Meij, A.J.W., Baart, J.A., Prahl-Andersen, B., et al. (2003) Outcome of bone grafting in relation to cleft width in unilateral cleft lip and palate patients. Oral Surgery Oral Medicine Oral Patholology Oral Radiology Endodontics, 96, 19-25. doi:10.1016/S1079-2104(03)00266-X

[6] Rawashdeh, M.A. and Telfah, H. (2008) Secondary alveolar bone grafting: The dilemma of donor site selection and morbidity. British Journal of Oral and Maxillofacial
Surgery, 46, 665-670. doi:10.1016/j.bjoms.2008.07.184

[7] Abramowicz, S., Katsnelson, A., Forbes, P.W., et al. (2012) Anterior versus posterior approach to iliac crest for alveolar cleft bone grafting. Journal of Oral and Maxillofacial Surgery, 70, 211-215.

doi:10.1016/j.joms.2011.02.044

[8] Wörtche, R., Hassfield, S., Lux, C.J., et al. (2006) Clinical application of cone beam digital volume tomography in children with cleft lip and palate. Dentomaxillfacial Radiology, 35, 88-94. doi:10.1259/dmfr/27536604

[9] Bähr, W. and Coulon, J.P. (1996) Limits of the mandibular symphysis as a donor site for bone grafts in early secondary cleft palate osteoplasty. International Journal of Oral and Maxillofacial Surgery, 25, 389-393. doi:10.1016/S0901-5027(06)80039-1

[10] Horswell, B.B. and Henderson, J.M. (2003) Secondary osteoplasty of the alveolar cleft defect. Journal of Oral and Maxillofacial Surgery, 61, 1082-1090. doi:10.1016/S0278-2391(03)00322-7

[11] Daw, J.L. and Patel, P.K. (2004) Management of alveolar clefts. Clinics of Plastic Surgery, 31, 303-313. doi:10.1016/S0094-1298(03)00129-9

[12] Boyne, P.J. and Sands, N.R. (1972) Secondary bone grafting of residual alveolar and palatal clefts. Journal of Oral Surgery, 30, 87-92.

[13] Rawashdeh, M.A. and Al Nimri, K.S. (2007) Outcome of secondary alveolar bone grafting before and after eruption of the canine in Jordanian patients with cleft lip and palate. Journal of Craniofacial Surgery, 18, 1331-1337. doi:10.1097/scs.0b013e31814e059b

[14] Eufinger, H. and Leppänen, H. (2000) Iliac crest donor site morbidity following open and closed methods of bone harvest for alveolar cleft osteoplasty. Journal of Craniomaxillofacial Surgery, 28, 31-38. doi:10.1054/jcms.2000.0105

[15] Sadove, A.M., Nelson, C.L., Eppley, B.L., et al. (1990) An evaluation of calvarial and iliac donor sites in alveolar cleft grafting. Cleft Palate Journal, 27, 225-259. doi:10.1597/1545-1569(1990)027<0225:AEOCAI $>2.3 . C$ $\underline{\mathrm{O} ; 2}$

[16] Canady, J.W., Zeitler, D.P., Thompson, S.A., et al. (1993) Suitability of the iliac crest as a site for harvest of autogenous bone grafts. Cleft Palate-Craniofacial Journal, 30, 579-581.

doi:10.1597/1545-1569(1993)030<0579:SOTICA $>2.3 . C$ $\underline{\mathrm{O} ; 2}$

[17] Petrungaro, P. (2001) Platelet-rich plasma for dental implants and soft-tissue grafting. Interview by Arun K. Garg. Dental Implantology Update, 12, 41-46.

[18] Petrungaro, P.S. (2001) Using platelet-rich plasma to accelerate soft tissue maturation in esthetic periodontal surgery. Compendium of Continuing Education in Dentistry, 22, 729-732.

[19] Kimura, A., Ogata, H., Yazawa, M., et al. (2005) The effects of platelet-rich plasma on cutaneous incisional wound healing in rats. Journal of Dermatological Science, 40, 205-208. doi:10.1016/j.jdermsci.2005.07.007 
[20] Eppley, B.L., Pietrzak, W.S. and Blanton, M. (2006) Platelet-rich plasma: A review of biology and applications in plastic surgery. Plastic and Reconstructive Surgery, 118, 147e-159e. doi:10.1097/01.prs.0000239606.92676.cf

[21] Motohashi, N. and Pruzansky, S. (1981) Long-term effects of premaxillary excision in patients with complete bilateral cleft lips and palates. Cleft Palate Journal, 18, 177-187.

[22] Aburezq, H., Daskalogiannakis, J. and Forrest, C. (2006) Management of the prominent premaxilla in bilateral cleft lip and palate. The Cleft Palate-Craniofacial Journal, 43, 92-95. doi:10.1597/04-114R.1

[23] Honma, K., Kobayashi, T., Nakajima, T., et al. (1999) Computed tomographic evaluation of bone formation after secondary bone grafting of alveolar clefts. Journal of Oral and Maxillofacial Surgery, 57, 1209-1213. doi:10.1016/S0278-2391(99)90488-3

[24] Keese, E. and Schmelzle, R. (1995) New findings concerning early bone grafting procedures in patients with cleft lip and palate. Journal of Cranio-Maxillofacial Surgery, 23, 296-301. doi:10.1016/S1010-5182(05)80159-3

[25] Long Jr., R.E., Spangler, B.E. and Yow, M. (1995) Cleft width and secondary alveolar bone graft success. Cleft Palate-Craniofacial Journal, 32, 420-427. doi:10.1597/1545-1569(1995)032<0420:CWASAB $>2.3$. $\underline{\mathrm{CO} ; 2}$

[26] Freihofer, H.P.M. and Kuypers-Jagtman, A.M. (1989) Early secondary osteoplastic closure of the residual alveolar cleft in combination with orthodontic treatment. Journal of Cranio-Maxillofacial Surgery, 17, 26-27. doi:10.1016/S1010-5182(89)80035-6

[27] Kalaaji, A., Lilja, J. and Friede, H. (1996) Bone grafting in the mixed and permanent dentition in cleft lip and palate patients: Long-term results and the role of the surgeon's experience. Journal of Cranio-Maxillofacial Surgery, 24, 29-35. doi:10.1016/S1010-5182(96)80074-6

[28] Williams, A., Semb, G., Bearn, D., et al. (2003) Prediction of outcomes of secondary alveolar bone grafting in children born with unilateral cleft lip and palate. European Journal of Orthodontics, 25, 205-211. doi:10.1093/ejo/25.2.205

[29] Van der Meij, A.J., Baart, J.A., Prahl-Andersen, B., et al. (1994) Computed tomography in evaluation of early secondary bone grafting. Internal Journal of Oral and Maxillofacial Surgery, 23, 132-136. doi:10.1016/S0901-5027(05)80286-3

[30] Van der Meij, A.J., Baart, J.A., Prahl-Andersen, B., et al. (2001) Bone volume after secondary bone grafting in unilateral and bilateral clefts determined by computed tomography scans. Oral Surgery Oral Medicine Oral Patholology Oral Radiology Endodontics, 92, 136-141. doi:10.1067/moe.2001.115274

[31] Tai, C.C., Sutherland, I.S. and McFadden, L. (2000) Prospective analysis of secondary alveolar bone grafting using computed tomography. Journal of Oral and Maxillofacial Surgery, 58, 1241-1249. doi:10.1053/joms.2000.16623

[32] Honma, K., Kobayashi, T., Nakajima, T., et al. (1999) Computed tomographic evaluation of bone formation after secondary bone grafting of alveolar clefts. Journal of Oral and Maxillofacial Surgery, 57, 1209-1213. doi:10.1016/S0278-2391(99)90488-3

[33] Yamazaki, M., Kanzaki, S., Tominaga, K., et al. (2011) Evaluation of secondary bone grafting of the alveolar cleft in adult cleft lip and palate patients. Asian Journal of Oral and Maxillofacial Surgery, in Press. doi:10.1016/j.ajoms.2011.10.001

[34] Kearns, G., Perrott, D.H., Sharma, A., et al. (1997) Placement of endosseous implants in grafted alveolar clefts. Cleft Palate-Craniofacial Journal, 34, 520-525. doi:10.1597/1545-1569(1997)034<0520:POEIIG >2.3.CO ;2

[35] Dempf, R., Teltzrow, T., Kramer, F.J., et al. (2002) Alveolar bone grafting in patients with complete clefts: A comparative study between secondary and tertiary bone grafting. Cleft Palate-Craniofacial Journal, 39, 18-25. doi:10.1597/1545-1569(2002)039<0018:ABGIPW >2.0.C $\underline{\mathrm{O} ; 2}$

[36] Takahashi, T., Inai, T., Kochi, S., et al. (2008) Longterm follow-up of dental implants placed in a grafted alveolar cleft: Evaluation of alveolar bone height. Oral Surgery Oral Medicine Oral Patholology Oral Radiology Endodontics, 105, 297-302. doi:10.1016/j.tripleo.2007.07.005

[37] Kichenaradjou, A., Beale, V.R. and Haers, B. (2010) Cystic change in alveolar bone graft. International Journal of Oral and Maxillofacial Surgery, 39, 615-616. doi:10.1016/j.ijom.2010.02.009

[38] Troxell, J.B., Fonseca, R.J. and Osbon, D.B. (1982) A retrospective study of alveolar cleft grafting. Journal of Oral and Maxillofacial Surgery, 40, 721-725. doi:10.1016/0278-2391(82)90145-8

[39] Hall, H.D. and Posnick, J.C. (1983) Early results of secondary bone grafts in 106 alveolar clefts. Journal of Oral and Maxillofacial Surgery, 41, 289-294. doi:10.1016/0278-2391(83)90295-1 